\title{
EFEKTIVITAS MODEL PENEMUAN TERBIMBING DENGAN MENGGUNAKAN TUGAS SUPERITEM TERHADAP KEMAMPUAN PEMECAHAN MASALAH MATEMATIKA MAHASISWA
}

\author{
Novi Mayasari $^{1}$, Anis Umi Khoirotunnisa ${ }^{2}$ \\ IKIP PGRI Bojonegoro, mahiraprimagrafika@ gmail.com ${ }^{1}$ \\ IKIP PGRI Bojonegoro, anis.umi@Ikippgribojonegoro.ac.id ${ }^{2}$ \\ Received : 30 Agustus 2018, Revised : 2 Oktober 2018, Accepted : 17 Oktober 2018 \\ (C) Mathematics Education Unugiri 2018
}

\begin{abstract}
This study aims to find out "the effectiveness of guided discovery models by using super-task tasks on the development of students' mathematical problem solving abilities". This research is designed by using posttest only control which the research subject is first year students of 2018/2019 academic year. This research uses saturated sampling technique because all members of the population are used as samples. Data collection techniques in this study only use test instruments. Data analysis technique was done by using t-test. The results of the data analysis obtained that hypothesis testing in the experimental and control class obtained $\mathrm{t}$ calculation $=3.41$ with $\mathrm{t}$ table $=$ 1.67. Because $t$ calculation $>\mathrm{t}$ table then $\mathrm{H} 0$ is rejected so that it can be concluded that the guided discovery learning model by using superchemical tasks is more effective than the direct learning model on mathematical problemsolving abilities of first-level students in school mathematics II even semester at IKIP PGRI Bojonegoro.
\end{abstract}

Keywords : guided discovery, superitem, solution to problem

\begin{abstract}
ABSTRAK
Penelitian ini bertujuan untuk mengetahui "efektivitas model penemuan terbimbing dengan menggunakan tugas superitem terhadap pengembangan kemampuan pemecahan masalah matematika mahasiswa".Penelitian ini merupakan penelitian dengan desain yang digunakan adalah posttest only control dimana subyek penelitiannya adalah mahasiswa tingkat I tahun ajaran 2018/2019. Penelitian ini menggunakan teknik sampling jenuh karena semua anggota populasi dijadikan sebagai sampel. Teknik pengumpulan data dalam penelitian ini hanya menggunakan instrument tes. Teknik analisis data menggunakan uji-t. Hasil dari analisis data diperoleh uji hipotesis pada kelas eksperimen dan kontrol diperoleh $t_{\text {hitung }}=3,41$ dengan $t_{\text {tabel }}=1,67$. Karena $t_{\text {hitung }}>t_{\text {tabel }}$ maka $H_{0}$ ditolak sehingga dapat disimpulkan bahwa modelpembelajaran penemuan terbimbing dengan menggunakan tugas superitem lebih efektif dibandingkan dengan model pembelajaran langsung terhadap kemampuan pemecahan masalah matematika mahasiswa tingkat I pada mata kuliah matematika sekolah II semester genap di IKIP PGRI Bojonegoro.
\end{abstract}

\section{Kata Kunci : Penemuan terbimbing, superitem, pemecahan masalah}

\section{Pendahulan}

Pendidikan merupakan basic atau pondasi dasardalam menciptakan manusiamanusia yang berkualitas dan berakhlak. Oleh karena itu Pendidikan memerlukan inovasiinovasi yang sesuai dengan ilmu pengetahuan dan teknologi yang berkembang tanpa mengabaikan nilai-nilai kemanusiaan.
Pendidikan juga dipandang sebagai sarana untuk melahirkan insan-insan yang cerdas, kreatif, terampil, bertanggung jawab, produktif, dan berbudi pekerti yang luhur.

Kondisi di atas, merupakan harapan ideal yang menjadi cita-cita bangsa ini. Namun realitasnya dunia pendidikan di Indonesia masih jauh dari keinginan tersebut. 
Keberhasilan suatu proses pembelajaran matematika di samping tergantung pada kemampuan pengajar dalam mengajar juga tergantung pada mahasiswa. Misalnya, bagaimana kemampuan pemecahan masalah matematis mahasiswa untuk menyelesaikan sebuah soal. Pada kenyataannya sebagian besar mahasiswa mempunyai tingkat perhatian dan kemampuan pemahaman dan pemecahan masalah yang berbeda terhadap pelajaran matematika. Mungkin pada dasarnya mahasiswa mengetahui maksud dan tujuan dari pembelajaran matematika, serta memahami materi, namun karena matematika lebih bersifat abstrak serta monoton kebanyakan mahasiswa kesulitan jika harus menuliskan sendiri gagasan dan pemikiran-pemikiran mereka sendiri

Berdasarkan hasil wawancara dengan dosen yang mengampu mata kuliah matematika sekolah 2 di IKIP PGRI Bojonegoro, didapat nilai UTS dan UAS pada semester ganjil tahun sebelumnya pada mata kuliah matematika sekolah II bahwa nilai ratarata tergolong rendaH masih di bawah rata-rata sekitar 6,5 (C) sedangkan untuk mendapatkan nilai $\mathrm{B}$ harus diatas 7,0. Hal ini dapat diketahui bahwa mahasiswa mengalami kesulitan dalam menyelesaikan soal-soal bertipe pemecahan masalah matematis dan menerjemahkan soal dalam kehidupan sehari-hari ke model matematika, khusunya pada materi yang bersifat abstrak seperti trigonometri. Berdasarkan hal tersebut, dapat disimpulkan bahwa siswa sulit memahami konsep-konsep matematika karena konsep-konsep matematika tersebut bersifat abstrak. Selain itu ada faktor lain yaitu kurangnya interaksi antara dosen dengan mahasiswa dalam proses pembelajaran masih rendah, kebanyakan mahasiswa tidak mau bertanya apabila ada materi yang belum sepenuhnya mengerti, sehingga pengajar sulit memahami kemampuan pemecahan masalah matematis siswa terhadap konsep matematika yang mereka pelajari.

Berdasarkan uraian di atas, maka perlu dilakukan perubahan dalam menerapkan model pembelajaran matematika, yang mana dengan menerapkan model pembelajaran yang lebih inovatif diharapkan dapat menjadi wadah bagi mahasiswa untuk membantu dalam memecahkan masalah dan dapat memberikan hasil belajar yang memuaskan. Salah satu wadah yang sesuai adalah penggunaan model pembelajaran penemuan terbimbing dengan tugas superitem

Menurut Jerome Bruner dalam markaban "penemuan adalah suatu proses, suatu jalan/cara dalam mendekati permasalahan bukannya suatu produk atau iten pengetahuan tertentu". Dengan demikian di dalam pandangan Bruner, belajar dengan penemuan adalah belajar untuk menemukan, dimana seorang mahasiswa dihadapkan dengan suatu masalah atau situasi yang tampaknya ganjil sehingga mahasiswa dapat mencari jalan pemecahan.[4]

Khusunya dalam Merumuskan masalah yang akan diberikan kepada mahasiswa harus dilengkapi dengan data secukupnya. Sehingga Perumusannya harus jelas, hindari pernyataan yang menimbulkan salah tafsir sehingga arah yang ditempuh mahasiswa tidak salah.Oleh karena itu model penemuan terbimbing diharapkan mahasiswa dalam menyusun, memproses, mengorganisir, dan menganalisis data lebih teliti dan benar. Sehingga model penemuan terbimbing dapat mengarahkan mahasiswa untuk melangkah kearah yang hendak dituju, melalui pertanyaan-pertanyaan, LKS atau modul. Mahasiswa menyusun konjektur (prakiraan) dari hasil analisis yang dilakukannya. Bila dipandang perlu,konjektur yang telah dibuat oleh mahasiswa tersebut diatas diperiksa oleh dosen. Hal ini penting dilakukan untuk menyakinkan prakiraan mahasiswa, sehingga akan menuju arah yang hendak dicapai. Apabila telah diperoleh kepastian tentang kebenaran konjektur, maka verbalisasi konjektur sebaiknya diserahkan juga kepada mahasiswa untuk menyusunnya. Sesudah mahasiswa menemukanapa yang dicari hendaknya dosen menyediakan soal latihan atau soal tambahan untuk memeriksa apakah penemuan itu benar. Adapun kelebihan pengunaan model penemuan terbimbing diantaranya mahasiswa dapat berpartisipasi 
aktif dalam pembelajaran yang disajikan, Menumbuhkan sekaligus menanamkan sikap inguiry (mencari-temukan). Dan Mendukung kemampuan problem solving siswa.

Berdasarkan beberapa alasan diatas peneliti berinisiatif dan berinovatif menerapkan model pembelajaran yang dimodifikasi dengan tugas superitem. Superitem terdiri dari sebuah stemyang diikuti beberapa pertanyaan atau item yang semakin meningkat kekompleksannya. Biasanya setiap superitem terdiri dari empat item pada masingmasing stem. Setiap item menggambarkan dari empat level penalaran berdasarkan Taksonomi SOLO. Semua item dapat dijawab dengan merujuk secara langsung pada informasi dalam sistem dan tidak dikerjakan dengan mengandalkan respon yang benar dari item sebelumnya. Pada level 1 diperlukan penggunaan satu bagian informasi dari stem. Level 2 diperlukan dua atau lebih bagian informasi dari stem. Pada level 3 siswa harus mengintegrasikan dua atau lebih bagian dari informasi yang tidak secara langsung berhubungan dengan stem, dan pada level 4 siswa telah dapat mendefinisikan hipotesis yang diturunkan dari stem. Karakteristik soalsoal bentuk superitem yang memuat konsep dan proses yang makin tinggi tingkat kognitifnya tersebut, memberi peluang kepada siswa dalam mengembangkan pengetahuannya dan memahami hubungan antar konsep.

Menurut Bigg dan Collis Dengan model Pembelajaran penemuan terbimbing dengan menggunakan tugas superitem, selain mengarahkan siswa menemukan sendiri konsep, aturan, dan prosedur, sehingga dapat terpakai secara maksimal, serta diharapkan mahasiswa terbiasa mengkomunikasikan ideide secara lisan maupun tulisan dalam rangka memecahan masalah terutama matematika dan akhirnya dapat meningkatkan hasil belajar siswa.[1]

Dan berdasarkan hasil penelitian terdahulu menurut Siti Maesaroh menyimpulkan bahwa Kemampuan Penalaran Matematis Siswa SMA meningkat Melalui
Pembelajaran Penemuan Terbimbing dengan Menggunakan Tugas Bentuk Superitem. [3]

Berdasarkan uraian diatas, peneliti tertarik untuk melakukan penelitian dengan judul "Efektivitas Model Penemuan Terbimbing dengan Menggunakan Tugas Superitem Terhadap Kemampuan Pemecahan Masalah Matematika Mahasiswa Tingkat I Pada Mata Kuliah Matematika Sekolh II Semester Genap di IKIP PGRI Bojonegoro"

Rumusan Masalah dalam penelitian ini adalah Apakah model pembelajaran penemuan terbimbing dengan menggunakan tugas superitem lebih efektif dibandingkan dengan model pembelajaran langsung terhadap kemampuan pemecahan masalah matematika mahasiswa tingkat I pada mata kuliah matematika sekolah II semester genap di IKIP PGRI Bojonegoro?.

Berdasarkan Rumusan masalah di atas maka tujuan dari penelitian ini adalahUntuk mengetahui apakah model pembelajaran penemuan terbimbing dengan menggunakan tugas superitem lebih efektif dibandingkan dengna model pembelajaran langsung terhadap kemampuan pemecahan masalah matematika mahasiswa tingkat I pada mata kuliah matematika sekolah II semester genap di IKIP PGRI Bojonegoro. Luaran wajibdari Penelitian ini adalah publikasi ilmiah dalam jurnal lokal yang mempunyai ISSN atau jurnal nasional terakreditasi.

Pembelajaran ini nantinya akan diterapkan di IKIP PGRI Bojonegoro yaitu pembelajaran penemuan terbimbing dengan tugas superitem yang bertujuan untuk meningkatkan kemampuan mahasiswa dalam pemecahan masalah matematika.

\section{Pembahasan}

Penelitian ini merupakan penelitian dengan desain yang digunakan adalah posttest only control dimana subyek penelitiannya adalah mahasiswa tingkat I tahun ajaran 2018/2019. Penelitian ini menggunakan teknik sampling jenuh karena semua anggota populasi dijadikan sebagai sampel. Menurut Budiyono Sampling jenuh adalah teknik pengambilan 
sampel dimana semua anggota populasi digunakan sampel.

Adapun tahapan dalam penelitian ini adalah Tahap pertama (Pelaksanannya dalam kurun waktu 2 bulan pertama) Pada tahap pertama yang dilakukan peneliti adalah penentuan sampel penelitian dan pengambilan data serta pengolahan data tentang prestasi belajar mahasiswa pada sampel; Tahap kedua (Pelaksanaanya dalam kurun waktu setelah tahap pertama selesai) Pada tahap kedua yang dilakukan peneliti meliputi Penyusunan perangkat pembelajaran yaitu Silabus, RPP, penyusunan soal serta pemvalidasian soal yang dilakukan oleh Nur Rohman, M.Pd dan Ari Indriani, M.Pd. selaku dosen yang dianggap mampu dalam bidang matematika. Langkah selanjutnya bila soal sudah memenhi kevalidannya barulah diujicobakan ke mahasiswa; Tahap ketiga (Pelaksanaanya dalam kurun waktu 6 bulan setelah tahap kedua)Proses kegiatan pada tahap ini adalah penelitian untuk membuktikan efektivitaq) penerapan model pembelajaran penemuan terbimbing dengan menggunakan tugas superitem terhadap kemampuan pemecahan masalah matematik mahasiswa tingkat I pada mata kuliah matematika sekolah II semester genap di IKIP PGRI Bojonegoro. Peneltian ini dijadwalkan 3 bulan untuk mendapatkan data prestasi belajar mahasiswa pada mata kuliah matematika sekolah II. Dan tersisa waktu 3 bulan digunakan peneliti untuk menganalisis data penelitian dan penyusunan laporan.

Instrumen yang digunakan untuk pengumpul data sebagai berikut: Dokumentasi digunakan untuk mengambil data UAS mahasiswa semester ganjil tingkat I sebagai bahan pertimbangan; Untuk uji validitas, uji reliabilitas, dan uji konsistensi internal digunakan angket; Untuk prestasf) belajar kepada siswa digunakan tes soal-soal matematika berbentuk essay 10 soal.

Teknis Analisis Data dalam penelitian ini dilakukan beberapa uji meliputi uji normalitas menggunakan uji lilifors, uji homogenitas menggunakan uji $f$ dan uji keseimbangan serta uji hipotesis menggunakan uji-t.

\subsection{Hasil Uji Coba Instrumen}

Kegiatan uji coba instrumen dilakukan untuk mengetahui validitas, reliabilitas, tingkat kesukaran, dan daya pembeda soal tes prestasi belajar. Uji coba instrumen dilakukan di tingkat I IKIP PGRI Bojonegoro (bukan kelas eksperimen dan bukan kelas kontrol) dengan jumlah siswa sebanyak 30 siswa pada tanggal 2 Mei 2018. Soal-soal uji coba terdiri dari 10 soal essay pada pada mata kuliah matematika sekolah II pada pokok bahasan lingkaran, trigonometri, pelung, permutasi dan kombinasi, serta penyajian data.

\section{Uji Prasyarat}

Uji prasyarat meliputi uji normalitas, uji homogenitas, dan uji keseimbangan yang dilakukan pada data sampel. Data berasal dari nilai UAS matematika semester ganjil tahun pelajaran 2016/2017 pada tingkat I matematika di IKIP PGRI Bojonegoro.

\section{1) Uji Normalitas}

Uji normalitas dengan metode Lilliefors untuk setiap kelas dengan tingkat signifikansi $\alpha=5 \%$. Daerah kritis untuk uji ini yaitu $\mathrm{DK}=$ $\{\mathrm{L} \mid \mathrm{L}>0,14\}$. Hasil analisis uji normalitas dapat dilihat pada tabel rangkuman berikut:

Tabel 1. Rangkuman Hasil Uji Normalitas

\begin{tabular}{llll}
\hline \multicolumn{1}{c}{ Kelompok } & $\mathrm{L}_{\mathrm{obs}}$ & $\mathrm{L}_{\text {tabel }}$ & Keputusan Uji \\
\hline Eksperimen & 0,12 & 0,14 & Ho diterima \\
Kontrol & 0,12 & 0,14 & Ho diterima \\
\hline
\end{tabular}

Berdasarkan tabel di atas, untuk masingmasing nilai dari $\mathrm{L}_{\text {obs }}<\mathrm{L}_{\text {tabel }}$ sehingga $\mathrm{Ho}$ diterima. Ini berarti bahwa masing-masing sampel berasal dari populasi yang berdistribusi normal.

\section{2) Uji Homogenitas}

Uji homogenitas dilakukan dengan uji $\mathrm{F}$ dengan dk penyebut $=39 \mathrm{dan} \mathrm{dk}$ pembilang $=39$ serta taraf signifikansi yaitu $\alpha=5 \%$. Harga Ftabel $=1,76$ dan harga Fhitung = 0,657 . Ini berarti Fhitung < Ftabel $(0,657<$ 1,76) jadi Ho diterima.Berdasarkan hasil analisis uji homogenitas dapat disimpulkan 
bahwa variansi-variansi dari kelas eksperimen dan kelas kontrol adalah sama (homogen).

\section{3) Uji Keseimbangan}

Uji keseimbangan pada penelitian ini dengan uji t pada tingkat signifikansi $\alpha=5 \%$. Hasil penghitungan didapatkan nilai $F_{o b s}$ $=1,989$. Daerah kritik untuk uji ini yaitu DK = $\{\mathrm{t} \mid \mathrm{t}<-2,009$ atau $\mathrm{t}>2,009\}$. Nilai $\mathrm{t}_{\mathrm{obs}} \in \mathrm{DK}$
sehingga Ho diterima.

Berdasarkan hasil analisis uji keseimbangan dapat disimpulkan bahwa siswa kelompok eksperimen dan kelompok kontrol memiliki kemampuan awal yang sama.

\subsection{Deskripsi Data Prestasi Belajar}

Data nilai kemampuan pemecahan masalah matematika pada kelompok eksperimen dengan menggunakan pembelajaran model penemuan terbimbing dengan tugas superitem dan kelompok kontrol dengan menggunakan pembelajaran langsung.

Tabel 2. Deskripsi Data Prestasi Belajar Matematika

\begin{tabular}{lcc}
\hline \multicolumn{1}{c}{ Kelompok } & Rata-rata & Varians \\
\hline Eksperimen & 81,53 & 147,8 \\
Kontrol & 77,86 & 110,2 \\
\hline
\end{tabular}

Data pada tabel menunjukkan bahwa nilai rata-rata siswa pada kelompok eksperimen lebih tinggi daripada nilai rata-rata siswa pada kelompok kontrol.

\subsection{Analisis Data}

Data nilai tes prestasi belajar matematika yang didapatkan selanjutnya dilakukan analisis data yang meliputi uji prasyarat, dan uji hipotesis penelitian.

\section{Uji Prasyarat}

Uji prasyarat meliputi uji normalitas dan uji homogenitas yang dilakukan pada data sampel. Data berasal dari nilai tes pemecahan masalah matematika pada mahasiswa tingkat I di IKIP PGRI Bojonegoro.

\section{1) Uji Normalitas}

Uji normalitas dengan metode Lilliefors untuk setiap kelas dengan tingkat signifikansi $\alpha=5 \%$. Daerah kritik untuk uji ini yaitu $\mathrm{DK}=$
$\{\mathrm{L} \mid \mathrm{L}>0,166\}$. Hasil analisis uji normalitas dapat dilihat pada tabel rangkuman berikut:

Tabel 3. Rangkuman Hasil Uji Normalitas

\begin{tabular}{llll}
\multicolumn{1}{c}{ Kelompok } & L $_{\text {obs }}$ & L tabel & Keputusan Uji \\
\hline Eksperimen & 0,11 & 0,16 & Ho diterima \\
Kontrol & 0,12 & 0,16 & Ho diterima \\
\hline
\end{tabular}

Berdasarkan tabel di atas, untuk masingmasing nilai dari $\mathrm{L}_{\text {obs }}<\mathrm{L}_{\text {tabel }}$ sehingga $\mathrm{Ho}$ diterima. Ini berarti bahwa masing-masing sampel berasal dari populasi yang berdistribusi normal.

\section{4) 2) Uji Homogenitas}

Uji homogenitas dilakukan dengan uji $\mathrm{F}$ dengan $\mathrm{dk}$ penyebut $=29 \mathrm{dan} \mathrm{dk}$ pembilang $=$ 29 serta taraf signifikansi yaitu $\alpha=5 \%$. Harga $F_{\text {tabel }}=1,85$ dan harga $F_{\text {hitung }}=1,341$. Ini berarti $F_{\text {hitung }}<F_{\text {tabel }}(1,341<1,85)$ jadi Ho diterima.

Berdasarkan hasil analisis uji homogenitas dapat disimpulkan bahwa variansi-variansi dari kelas eksperimen dan kelas kontrol adalah sama (homogen).

\section{Uji Hipotesis Penelitian}

Uji hipotesis dalam penelitian ini dilakukan dengan uji $\mathrm{t}$ menggunakan rumus separated varians. Taraf signifikansi yang telah ditetapkan yaitu $\alpha=5 \%$ dan $\mathrm{dk}=54$. Harga $t_{\text {tabel }}=1,67$ dan harga $t_{\text {hitung }}=3,41$. Harga $t_{\text {hitung }}>t_{\text {tabel }}$, dengan demikian Ho ditolak dan $\mathrm{H}_{1}$ diterima.

Berdasarkan hasil analisis uji hipotesis dapat disimpulkan bahwa modelpembelajaran penemuan terbimbing dengan menggunakan tugas superitem lebih efektif dibandingkan dengan model pembelajaran langsung terhadap kemampuan pemecahan masalah matematika mahasiswa tingkat I pada mata kuliah matematika sekolah II semester genap di IKIP PGRI Bojonegoro.

Berdasarkan dari hasil anasilis data diatas, hasil belajar mahasiswa kelas eksperimen lebih baik dari pada hasil belajar kelas kontrol. Hal itu dikarenakan pada pembelajaran kelas eksperimen proses pembelajaran menggunakan model 
pembelajaran penemuan terbimbng dengan tugas superitem. Pada awal penelitian ini dijelaskan bahwa metode penelitian menggunakan sistem sampling jenuh, yaitu semua populasi digunakan sebagai sampel, dengan begitu dapat dijelaskan bahwa keberhasilan menggunakan model pembelajaran penemuan terbimbing deengan tugas superitem dapat berlaku disetiap kelas dalam populasi. Model pembelajaran penemuan terbimbing dengan tugas superitem yang digunakan dapat memberikan hasil belajar yang baik bagi siswa, salah satunya digunakan dalam pembelajaran yang mengajarkan perlunya siswa menyelesaikan soal pemecahan masalah matematika, dikarenakan pada pembelajaran ini siswa melalui beberapa tahap.

Menurut Markaban, Adapun tahapan dari model pembelajaran penemuan terbimbing dengan tugas item yaitu Pertama, Merumuskan masalah yang akan diberikan kepada mahasiswa dengan data secukupnya. Perumusannya harus jelas, hindari pernyataan yang menimbulkan salah tafsir sehingga arah yang ditempuh siswa tidak salah. Kedua, Dari data yang diberikan dosen,mahasiswa menyusun, memproses, mengorganisir, dan menganalisis data tersebut. Dalam hal ini, bimbingan ini sebaiknya mengarahkan siswa untuk melangkah kearah yang hendak dituju, melalui pertanyaan-pertanyaan, atau LKS. Ketiga mahasiswa menyusun konjektur (prakiraan) dari hasil analisis yang dilakukannya. Keempat, Bila dipandang perlu,konjektur yang telah dibuat oleh mahasiswa tersebut diatas diperiksa oleh dosen. Hal ini penting dilakukan untuk menyakinkan prakiraan mahasiswa, sehingga akan menuju arah yang hendak dicapai. Kelima, Apabila telah diperoleh kepastian tentang kebenaran konjektur, maka verbalisasi konjektur sebaiknya diserahkan juga kepada mahasiswa untuk menyusunnya. Kelima, Sesudah mahasiswa menemukan apa yang dicari hendaknya dosen menyediakan soallatihan atau soal tambahan untuk memeriksa apakah penemuan itu benar.[4]
Berdasarkan hasil pembelajaran penemuan terbimbing dengan tugas superitem yang dilakukan secara bertahap dari hari kehari dapat ditarik kesimpulan bahwa dengan menerapkan model penemuan terbimbing dengan tugas superitemlebih efektif dibandingkan dengan model pembelajaran langsung terhadap kemampuan pemecahan masalah matematika mahasiswa tingkat I pada mata kuliah matematika sekolah II semester genap di IKIP PGRI Bojonegoro.

\section{Penutup}

Uji hipotesis dilakukan dengan menggunakan uji t dengan rumus separated varians. Hasil analisis yang telah diuraikan pada bab IV menunjukkan bahwa harga $t_{\text {hitung }}=$ $3,41>t_{\text {tabel }}=1,67$ dengan nilai rata-rata kelas eksperimen yaitu $\overline{\mathrm{x}}_{1}=81,53$ dan nilai rata-rata kelas kontrol $\overline{\mathrm{x}}_{2}=77,86$, jadi didapatkan bahwa Ho ditolak dan $\mathrm{H}_{1}$ diterima. Kesimpulan pada penelitian ini yaitu bahwa modelpembelajaran penemuan terbimbing dengan menggunakan tugas superitem lebih efektif dibandingkan dengan model pembelajaran langsung terhadap kemampuan pemecahan masalah matematika mahasiswa tingkat I pada mata kuliah matematika sekolah II semester genap di IKIP PGRI Bojonegoro.

\section{Referensi}

[1] Bigg, J. B. dan Collis, Evaluating The Quality of Learning : The Solo Taxonomy, New York: Akademik Press Inc. (1982)

[2] Budiyono, Metode Penelitian Pendidikan, Surakarta: UNS Press. (2003).

[3] Maesaroh, S., Meningkatkan Kemampuan Penalaran Matematis Siswa SMA Melalui Pembelajaran Penemuan Terbimbing dengan Menggunakan Tugas Bentuk Superitem, Bandung: UPI (tidak diterbitkan). (2007).

[4] Markaban. Model Penemuan Terbimbing Pada Pembelajaran Matematika SMK. Yogyakarta : Pusat Pengembangan dan Pemberdayaan Pendidik dan Tenaga Kependidikan Matematika. (2006). 